\title{
Cotylenin A and tyrosine kinase inhibitors synergistically inhibit the growth of chronic myeloid leukemia cells
}

\author{
FUMIYOSHI IKEJIRI $^{1}$, YOSHIO HONMA ${ }^{1,2}$, TAKAHIRO OKADA $^{1}$, TAKESHI URANO ${ }^{2}$ and JUNJI SUZUMIYA ${ }^{1}$ \\ Departments of ${ }^{1}$ Oncology/Hematology and ${ }^{2}$ Biochemistry, Faculty of Medicine, \\ Shimane University, Izumo, Shimane 6938501, Japan
}

Received January 11, 2018; Accepted March 21, 2018

DOI: $10.3892 /$ ijo.2018.4350

\begin{abstract}
The treatment of chronic myeloid leukemia (CML) with tyrosine kinase inhibitors (TKIs) has substantially extended patient survival. However, TKIs do not effectively eliminate CML stem cells. In fact, CML stem cells persist and cause relapse in the majority of patients upon discontinuation of the drug treatment. Transcriptomic and proteomic analyses have revealed that p53 and c-Myc play defining roles in CML stem cell survival, suggesting that the dual targeting of p53 and c-Myc may selectively eliminate stem cells in patients with CML. Since the downregulation of c-Myc and then upregulation of p21 (a target gene of p53) are commonly observed during the differentiation of acute myeloid leukemia cells induced by differentiation inducers, we hypothesized that differentiation-inducing agents may be useful in regulating c-Myc and p53 expression in CML cells. In the present study, we demonstrate that some differentiation-inducing agents effectively suppress the self-renewal ability of CML cells, and that the combination of these inducers with TKIs results in significantly greater inhibitory effects on CML cell growth compared to the use of TKIs or the inducer alone. The KU812 cells were treated with various concentrations of the inducers in the presence or absence of $30 \mathrm{nM}$ imatinib for 4 days. Among the differentiation inducers we tested, cotylenin A (CN-A) was the most potent at inhibiting the self-renewal ability of the CML cells. CN-A induced the robust expression of CD38, a marker of committed progenitor and more differentiated myelomonocytic cells, and rapidly suppressed c-Myc expression and upregulated p21 expression in CML cells. Thus, these results suggest that $\mathrm{CN}-\mathrm{A}$ may have potential to promote the elimination of stem cells in CML.
\end{abstract}

Correspondence to: Professor Yoshio Honma, Department of Oncology/Hematology, Faculty of Medicine, Shimane University, 89-1 Enya, Izumo, Shimane 693-8501, Japan

E-mail: biohonma@med.shimane-u.ac.jp

Key words: chronic myeloid leukemia, stem cell, differentiation inducer, cotylenin A, tyrosine kinase inhibitor, c-Myc

\section{Introduction}

Chronic myeloid leukemia (CML), a clonal disease affecting hematopoietic stem cells, is driven by the BCR/ABL oncoprotein, a constitutively active tyrosine kinase. Patients with CML in the chronic phase are treated with imatinib (IM) or other tyrosine kinase inhibitors (TKIs), which are highly effective at inducing remission and prolonging survival. However, TKIs do not completely eliminate leukemia stem cells (LSCs), even in patients who achieve deep molecular responses (1-3). Thus, the identification of drugs that can target these LSCs is of primary importance in order to acheive the eradication of CML. Transcriptomic and proteomic analyses have revealed that p53 and c-Myc play defining roles in CML-LSC survival (4). These results suggest that the dual targeting of p53 and c-Myc may selectively eliminate LSCs in patients with CML.

Human and murine myeloid leukemia cells can be induced to differentiate into mature granulocytes and macrophages by various differentiation-inducing agents $(5,6)$. There are a number of methods with which to induce granulocytic or monocytic differentiation in leukemia cells, since differentiation-inducing agents act by different mechanisms to induce the production of more or less identical end-stage cells (7-9). However, the downregulation of c-Myc and the upregulation of p21 (a target gene of p53) are commonly observed during the differentiation of myeloid leukemia cells induced by various inducers of differentiation (10-12). These results suggest that differentiation-inducing agents may be useful regulators of c-Myc and p53 expression in leukemia cells.

In this study, we examined the effects of agents that induce the differentiation of acute myeloid leukemia (AML) cells on the proliferation of CML cells in the presence of TKIs. Among the former, cotylenin A (CN-A) was found to be the most effective at inhibiting the clonogenic potential and proliferation of CML cells in long-term culture in the presence of TKIs. CN-A, which is a novel fusicoccane-diterpene glycoside with a complex sugar moiety, has been shown to affect the differentiation of leukemia cells that have been freshly isolated from patients with AML in primary culture $(6,13)$. The administration of $\mathrm{CN}-\mathrm{A}$ has been shown to significantly prolonged the survival of mice inoculated with retinoid-resistant human promyelocytic leukemia NB4 cells, and no appreciable adverse effects were observed (14). These findings thus suggest that CN-A may be useful in CML therapy when combined with TKIs. 


\section{Materials and methods}

Materials. RPMI-1640 medium, all-trans retinoic acid (ATRA), doxorubicin, rapamycin and cytosine arabinoside (AraC) were purchased from Sigma-Aldrich Japan (Tokyo, Japan). Dimethyl sulfoxide (DMSO), 1 $\alpha, 25$-dihydroxy vitamin $\mathrm{D}_{3}(\mathrm{VD} 3)$ and sodium butyrate were purchased from Wako Chemicals (Osaka, Japan). CN-A was a gift from Professor Takeshi Sassa, phycoerythrin (PE)-labeled anti-CD38 antibody (cat. no. 555460) was obtained from BD Immunocytometry Systems (San Jose, CA, USA). IM, dasatinib (DAS) and nilotinib (NIL) were obtained from Selleck Chemicals (Houston, TX, USA).

Patients with leukemia. Leukemic bone marrow specimens were collected at diagnosis, after the patients provided written informed consent for sample collection in accordance with institutional policy. The Shimane University Institutional Committee on Ethics (Shimane, Japan) approved the present study. The samples were obtained from the following patients: Case 1 was a 71-year-old Japanese male who was admitted to the Department of Oncology/Hematology, Shimane University Hospital (Shimane, Japan), presenting with hyperleukocytosis. Laboratory data upon admission were white blood cell count (WBC) 169,040/ $\mu$; myelocytes, 13.5\%; metamyelocytes, 15.5\%; and lactate dehydrogenase (LDH), $861 \mathrm{U} / 1$. Samples from case 1 were obtained in November, 2017. Case 2 was a 64-year-old Japanese female who was admitted to the Department of Oncology/Hematology, Shimane University Hospital, presenting with hyperleukocytosis. Laboratory data upon admission were WBC, 60,420/ $\mu 1$; myelocytes, $12.7 \%$; metamyelocytes, $4.2 \%$; and LDH, $674 \mathrm{U} / 1$. Samples from case 2 were collected in December, 2017. In both cases, CML was diagnosed on the basis of bone marrow morphology and the standard cytogenetic translocation, $\mathrm{t}(9 ; 22)$, in $98 \%$ of the cells by fluorescence in situ hybridization (FISH) analysis.

Cells and cell culture. K562 (15) and KU812 (16) cells were obtained from the respective founders and were maintained in RPMI-1640 medium supplemented with $10 \%$ fetal bovine serum (Biowest, Nauille, France) and $80 \mu \mathrm{g} / \mathrm{ml}$ gentamicin (MSD Co., Ltd., Tokyo, Japan) at $37^{\circ} \mathrm{C}$ in a humidified atmosphere of $5 \% \mathrm{CO}_{2}$ in air.

Assay of cell growth and properties of differentiated cells. Suspensions of cells $\left(2 \times 10^{4}\right.$ cells $\left./ \mathrm{ml}\right)$ in $1 \mathrm{ml}$ of culture medium were incubated with or without the test compounds in multidishes. Cell numbers were counted using a Model Z1 Coulter Counter (Beckman Coulter, Tokyo, Japan). The growth inhibitory effects of the drugs were examined by determining the concentrations of drugs that were required to reduce the cell number to one-half of that in untreated cells $\left(\mathrm{IC}_{50}\right)$. Morphological changes were examined in cell smears stained with May-Grünwald-Giemsa solution (Merck Japan, Tokyo, Japan). The surface expression of CD38 was determined by monoclonal antibody labeling and flow cytometry using a FACScan flow cytometer (BD Biosciences, Franklin Lakes, NJ, USA), as previously described (13).

Assay of cumulative cell number. The cells $\left(2 \times 10^{4} / \mathrm{ml}\right)$ were cultured in medium with the test compounds. Thereafter, the cell density of the treated cells was kept at $1-8 \times 10^{5} / \mathrm{ml}$ to maintain the growth phase. The medium of treated cultures was replaced with fresh medium with or without the test compounds at least every 7 days. The cumulative cell number was calculated from the cell counts and the dilution used when feeding the culture. Cell numbers were counted using a Beckman Coulter Z1 Particle Counter.

Colony-forming assay. The K562 or KU812 cells $\left(3 \times 10^{3}\right.$ per dish) were plated into $2 \mathrm{ml}$ of a semi-solid medium with $0.8 \%$ methylcellulose and $20 \%$ fetal bovine serum in triplicate multiwell plates (12 wells, $3.5 \mathrm{~cm}^{2}$ growth area/well) for 7-14 days. A solution of $0.1 \mathrm{ml}$ of PBS containing various concentrations of the drugs was added to the semi-solid medium. To determine the colony-forming ability of the leukemia cells from patients with CML, heparinized bone marrow aspirations were diluted with RPMI-1640 medium supplemented with $10 \%$ fetal bovine serum, overlaid on $15 \mathrm{ml}$ of Ficoll-Paque Plus (GE Healthcare Biosciences, Uppsala, Sweden) and centrifuged at $500 \mathrm{x} \mathrm{g}$ for $30 \mathrm{~min}$. The mononuclear cells were washed twice and suspended in RPMI-1640 medium supplemented with $10 \%$ fetal bovine serum, plated in semi-solid culture medium with $20 \%$ serum at $10^{5}$ cells/dish for colony formation, and incubated at $37^{\circ} \mathrm{C}$ in a humidified atmosphere of $5 \% \mathrm{CO}_{2}$ in air. Colonies were photographed under an inverted microscope (Model CKX41; Olympus, Tokyo, Japan). In serial colony formation assays, the cells were serially replated after 7 days of culture.

Western blot analysis. The cells were packed after being washed with cold PBS, and then lysed at $1.5 \times 10^{7}$ cells $/ \mathrm{ml}$ in sample buffer [63 mM Tris- $\mathrm{HCl}$ ( $\mathrm{pH} 6.8), 15 \%$ glycerol, $2 \%$ sodium dodecyl sulfate (SDS), $5 \%$ 2-mercaptoethanol and $0.005 \%$ bromophenol blue]. The resultant lysates were resolved on $10 \%$ SDS-polyacrylamide gels. Protein concentration was quantified using the Protein Quantification kit-Rapid (Wako Pure Chemical Industries, Ltd.). Equal amounts of protein $(10 \mu \mathrm{g})$ were separated by SDS/PAGE (10\% gels) prior to transfer to polyvinylidene fluoride membranes (Bio-Rad Laboratories, Hercules, CA, USA), and then blocked with Block Ace (DS Pharma Biomedical Co., Ltd., Osaka, Japan) for $60 \mathrm{~min}$ at room temperature. The membranes were then immunoblotted with anti-p21 (\#2947), anti-cMyc (\#5606) and anti- $\beta$-actin (\#4970) antibodies (1:500 dilution) antibodies which were purchased from Cell Signaling Technology Japan (Tokyo, Japan). Horseradish peroxidase (HRP)-conjugated antibody (\#7074S and 7076S; Cell Signaling Technology, Danvers, MA, USA) was used as a secondary antibody (1:2,000 dilution). The bands were developed by treatment with the Immun-Star HRP Chemiluminescent kit (Bio-Rad Laboratories) for $5 \mathrm{~min}$ at room temperature, and detected using a Fuji Lumino Image Analyzer LAS-4000 system (Fuji Film, Tokyo, Japan).

Reverse transcription-quantitative polymerase chain reaction $(R T-q P C R)$. Total RNA was extracted from the cells using TRIzol reagent (Sigma-Aldrich). Total RNA was converted to first-strand cDNA primed with random hexamer in a reaction volume of $20 \mu \mathrm{l}$ using an RNA PCR kit (qPCR RT Master Mix; Toyobo Co., Ltd., Osaka, Japan), and $2 \mu 1$ of this reaction was used as a template in real-time PCR. The primers 
Table I. Effects of differentiation inducers on the growth of KU812 cells in the presence or absence of IM.

\begin{tabular}{|c|c|c|c|}
\hline \multirow[b]{2}{*}{ Compound } & \multirow[b]{2}{*}{ Concentration $^{\mathrm{a}}$} & \multicolumn{2}{|c|}{ Cumulative cell number $(/ \mathrm{ml})^{\mathrm{b}}$} \\
\hline & & None & +30 nM IM \\
\hline None & & $3,778,000 \pm 265,000$ & $920,000 \pm 73,000$ \\
\hline ATRA & $3 \mathrm{nM}$ & $412,000 \pm 26,000$ & $84,000 \pm 7,000$ \\
\hline $\mathrm{CN}-\mathrm{A}$ & $1.2 \mu \mathrm{g} / \mathrm{ml}(1.92 \mu \mathrm{M})$ & $54,000 \pm 4,200$ & $42,000 \pm 3,400$ \\
\hline VD3 & $300 \mathrm{nM}$ & $590,000 \pm 62,000$ & $186,400 \pm 12,000$ \\
\hline Butyrate & $730 \mu \mathrm{M}$ & $238,000 \pm 19,200$ & $178,000 \pm 12,600$ \\
\hline DMSO & $105 \mathrm{mM}$ & $265,000 \pm 22,000$ & $138,600 \pm 11,600$ \\
\hline Rapamycin & $0.13 \mathrm{nM}$ & $1,269,000 \pm 104,000$ & $138,800 \pm 14,200$ \\
\hline Doxorubicin & $12.7 \mathrm{nM}$ & $233,600 \pm 20,200$ & $167,200 \pm 13,600$ \\
\hline AraC & $1.7 \mathrm{nM}$ & $216,400 \pm 18,200$ & $76,000 \pm 6,200$ \\
\hline
\end{tabular}

${ }^{\mathrm{a}} \mathrm{IC}_{50}$ concentrations for 4 days. ${ }^{\mathrm{b}}$ Cells were cultured with various differentiation-inducing agents in the presence or absence of $30 \mathrm{nM} \mathrm{IM}$ for 14 days. Results are presented as the means \pm SD of 3 separate experiments.

were used as previously described (17). The quantitative PCR reaction was performed using a Takara TP860 Real-Time PCR system (Takara Bio, Tokyo, Japan) according to the manufacturer's instructions (40 cycles of duration at $95^{\circ} \mathrm{C}$ for $15 \mathrm{sec}$ and annealing and extension at $60^{\circ} \mathrm{C}$ for $60 \mathrm{sec}$ ). The threshold cycle values were normalized to the threshold value of glyceraldehyde-3-phosphate dehydrogenase. Data analysis was performed using the $2^{-\Delta \Delta \mathrm{Cq}}$ method (18).

Statistical analysis. The results are expressed as the means \pm standard deviation (SD). Statistical analysis was conducted with SPSS 19.0 software (IBM Japan, Tokyo, Japan). Statistical significance between multiple groups was determined by ANOVA with a Bonferroni post-hoc test, and between 2 groups using a Student's t-test. Significant differences were considered to exist for probabilities below $5 \%(\mathrm{P}<0.05)$.

\section{Results}

Combined effects of IM and differentiation-inducing agents on the proliferation of CML cells. IM inhibited the growth of the K562 and KU812 cells in a concentration dependent manner; the $\mathrm{IC}_{50}$ values at 7 days were 25 and $18 \mathrm{nM}$, respectively (data not shown). The KU812 cells were treated with 30, 60 and $100 \mathrm{nM}$ IM for 14 days, washed with PBS, resuspended in drug-free culture medium, and cultured for an additional 7 days. The cells were first treated with $100 \mathrm{nM}$ IM for 14 days. After washing, the cells were further treated without or with IM. While continuous IM treatment effectively suppressed proliferation, the depletion of IM from the medium allowed the cells to re-grow, indicating that IM did not completely block the ability of the cells to repopulate (Fig. 1A). Similar results were obtained when the K562 cells were treated with $100 \mathrm{nM}$ IM (data not shown). We then examined the effects of several agents that are known to induce the differentiation of AML cells on the proliferation of CML cells (Table I). KU812 cells were treated with various concentrations of the inducers in the presence or absence of $30 \mathrm{nM}$ IM. Most of the compounds we used effectively synergized with IM to inhibit the growth of KU812 cells. Low concentrations of ATRA and IM synergistically inhibited the proliferation of KU812 cells, but ATRA did not affect the proliferation of K562 cells even in the presence of IM. Combination of butyrate and IM was not evident, suggesting that butyrate is not a good partner of IM. On the other hand, $\mathrm{CN}-\mathrm{A}$ alone greatly inhibited the long-term proliferation of KU812 cells. In this condition, therefore, the combined effects with IM were modest. These results suggest that $\mathrm{CN}-\mathrm{A}$ at concentrations less than $\mathrm{IC}_{50}$ are enough to inhibit the long-term proliferation of CML cells in the presence of IM. The results of treatment with $\mathrm{IC}_{50}$ concentrations for 4 days are shown in Table I. CN-A was less cytotoxic than the other compounds tested, but was the most potent at inhibiting cell proliferation for 14 days (Table I), suggesting that CN-A effectively suppressed the self-renewal ability of these cells. CN-A and IM cooperatively inhibited cell proliferation (Fig. 1B). These compounds also exerted combined effects on the K562 cells. While the K562 cells that were treated with $2 \mu \mathrm{g} / \mathrm{ml}$ of CN-A or $30 \mathrm{nM}$ IM for 14 days still grew in the drug-free culture, those treated with $\mathrm{CN}-\mathrm{A}$ plus IM lost the ability to proliferate (Fig. 1C). Although CN-A alone hardly affected the apoptosis of the CML cells, it markedly enhanced the IM-induced apoptosis of the K562 cells (data not shown). These compounds also exerted combined effects on the clonogenic activity of the cells (Fig. 1D). The colony-forming ability of the K562 cells was markedly inhibited by treatment with $\mathrm{CN}-\mathrm{A}$ alone at a concentration of $>4 \mu \mathrm{g} / \mathrm{ml}$, and IM cooperatively inhibited the colony-forming ability of the $\mathrm{K} 562$ cells treated with $\mathrm{CN}-\mathrm{A}$. Treatment with $\mathrm{CN}-\mathrm{A}$ at $1 \mu \mathrm{g} / \mathrm{ml}$ completely suppressed the colony-forming ability of the KU812 cells and IM did not alter this effect of $\mathrm{CN}-\mathrm{A}$ on colony formation (data not shown).

The effectiveness of combined treatment with $\mathrm{CN}-\mathrm{A}$ and IM on primary CML cells was examined and compared with that of treatment with either IM or CN-A alone. CN-A significantly inhibited colony formation by leukemia cells from a patient with CML (case 1) (Fig. 2A). Although IM alone did not significantly suppress colony formation, it significantly enhanced the inhibitory effects of CN-A on colony formation (Fig. 2A and B). The clonogenic activity of the leukemia 
A

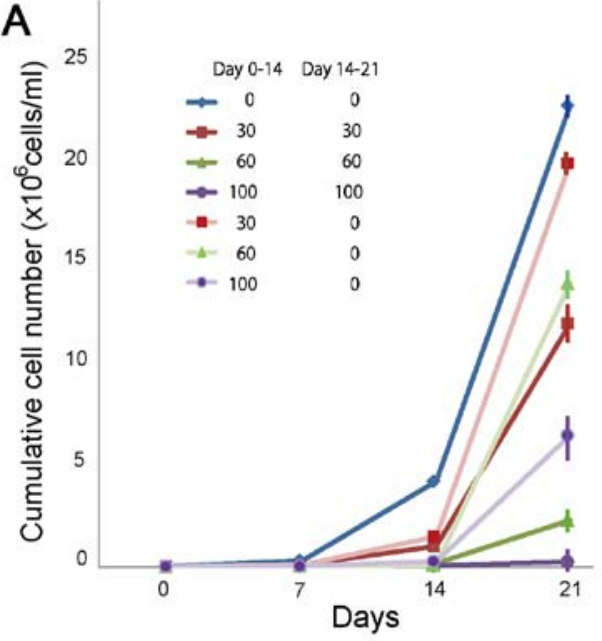

C

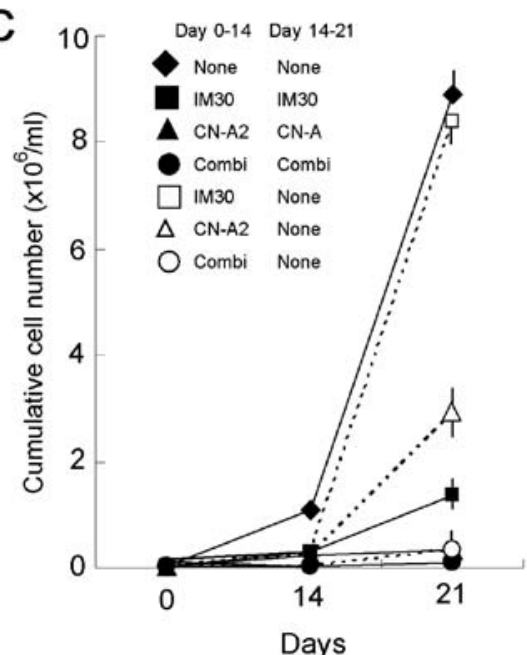

B

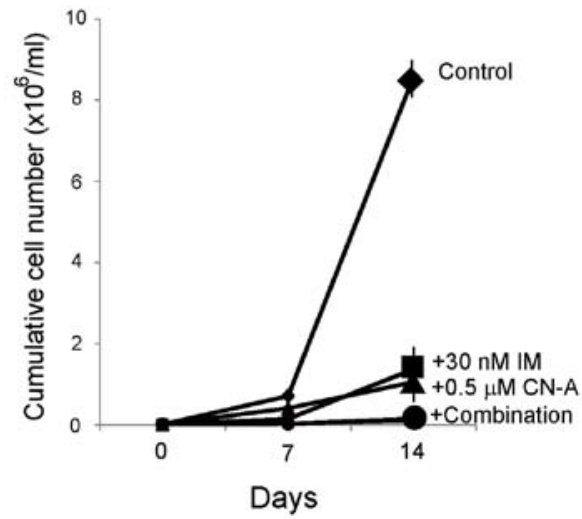

D
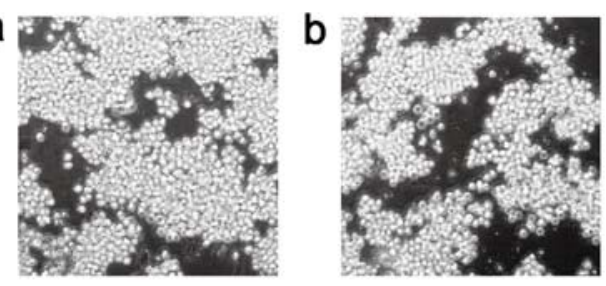

C
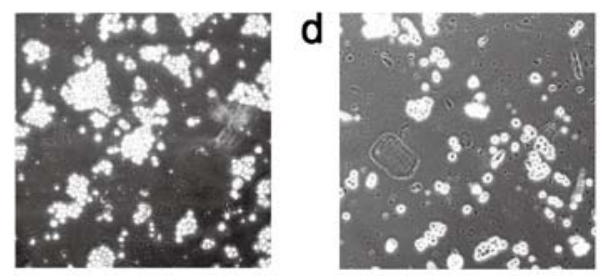

Figure 1. (A) Proliferation of KU812 cells in long-term culture with IM. The KU812 cells were first treated with 0,30, 60 or $100 \mathrm{nM}$ IM (indicated in the color key) for 14 days. After washing, the cells were treated with or without IM. The cell density of the IM-treated cells was kept at 1-8x $10^{5}$ cells $/ \mathrm{ml}$. Data are representative of the means \pm SD of 3 determinations. (B) Combined effects of CN-A and IM on the growth of KU812 cells. Cells were treated with $30 \mathrm{nM} \mathrm{IM} \mathrm{(-})$,

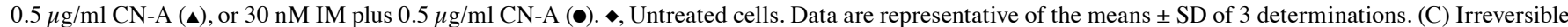
suppression of proliferation of K562 cells by combined treatment with CN-A and IM. Cells were treated with $30 \mathrm{nM} \mathrm{IM}(\mathbf{\bullet}), 2 \mu \mathrm{g} / \mathrm{ml} \mathrm{CN}-\mathrm{A}(\mathbf{\Delta})$, or $30 \mathrm{nM}$ IM plus $2 \mu \mathrm{g} / \mathrm{ml} \mathrm{CN-A}(\bullet)$ continuously. Cells were treated with $30 \mathrm{nM} \mathrm{IM}(\square), 2 \mu \mathrm{g} / \mathrm{ml} \mathrm{CN-A}(\triangle)$, or $30 \mathrm{nM}$ IM plus $2 \mu \mathrm{g} / \mathrm{ml} \mathrm{CN}-\mathrm{A}(0)$ for 14 days, and then washed and cultured without drugs. $\bullet$ Untreated cells. Data are representative of the means \pm SD of 3 determinations. (D) Colony formation of K562 cells with IM and/or CN-A. Cells were cultured (a) without or (b) with $30 \mathrm{IM}$, (c) $6 \mu \mathrm{g} / \mathrm{ml} \mathrm{CN-A}$, (d) or $30 \mathrm{IM}$ plus $6 \mu \mathrm{g} / \mathrm{ml} \mathrm{CN-A}$ for 7 days. IM, imatinib; CN-A, cotylenin A.

cells from case 2 was also inhibited by treatment with IM plus $\mathrm{CN}-\mathrm{A}$, although the combined effects on the cells from case 2 were less prominent than those on the cells from case 1 . The inhibitory effects of $\mathrm{CN}-\mathrm{A}$ on the stem cell potential of primary cells from case 2 were confirmed using serial colony formation assays (Fig. 2C). CN-A, alone or in combination with IM, completely reduced the replating efficiency of the cells from case 2. By contrast, treatment with $30 \mathrm{nM}$ IM did not reduce colony formation in secondary cultures from case 2 .

Two second-generation TKIs have been developed and represent viable alternatives to IM. Thus, we examined the combined effects of CN-A and these TKIs. Similar results were observed when the cells were treated with $\mathrm{CN}-\mathrm{A}$ plus other TKIs, such as DAS and NIL (Fig. 2D and E).

Modulation of the phenotypes of KU812 cells by $C N-A$. Since $\mathrm{CN}-\mathrm{A}$ is a potent inducer of the differentiation of AML cells $(6,13)$, in this study, we examined the effects of $\mathrm{CN}-\mathrm{A}$ on the differentiation-associated phenotypes of the K562 and KU812 cells. CN-A induced morphological changes in these cells, whereas ATRA, AraC and IM alone did not (Fig. 3A). The enlargement of the cytoplasm, decreased cytoplasmic basophilicity and compact nuclei were observed in the $\mathrm{CN}$-A-treated cells. In the KU812 cells, morphological changes induced by $\mathrm{CN}-\mathrm{A}$ were not affected by IM. CN-A did not induce CD11b expression, $\alpha$-naphthyl acetate esterase activity or the reduction of nitroblue tetrazolium (markers of myelomonocytic differentiation) in either cell line even in the presence of IM (data not shown), although $\mathrm{CN}-\mathrm{A}$ has been shown to effectively induce these differentiation-associated phenotypes in AML cell lines and AML cells in primary culture (13). Similar results were obtained in the CN-A-treated K562 cells (data not shown).

CD38 is an important marker of human hematopoietic stem cells. $\mathrm{CD} 34^{+} \mathrm{CD} 38^{-}$bone marrow cells are highly enriched for long-term repopulating hematopoietic stem cells, while $\mathrm{CD} 34{ }^{+} \mathrm{CD} 38^{+}$cells are more committed progenitor 


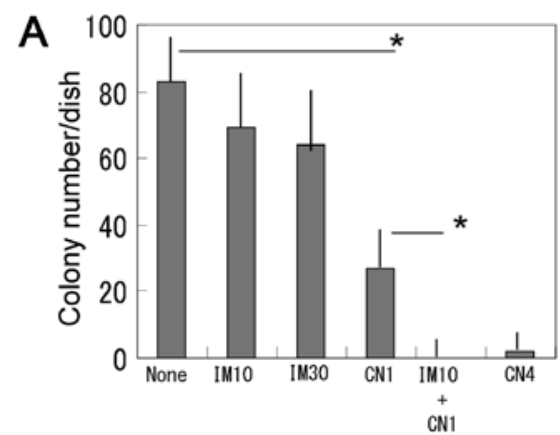

B a
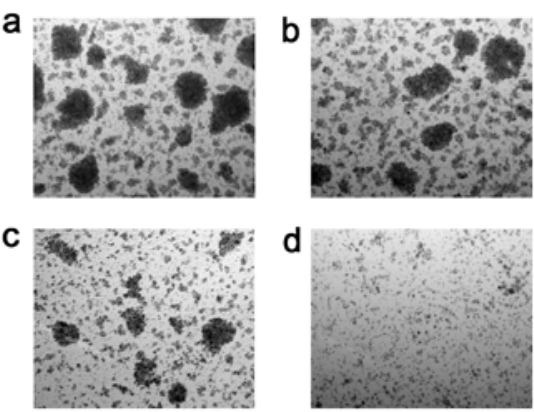

C
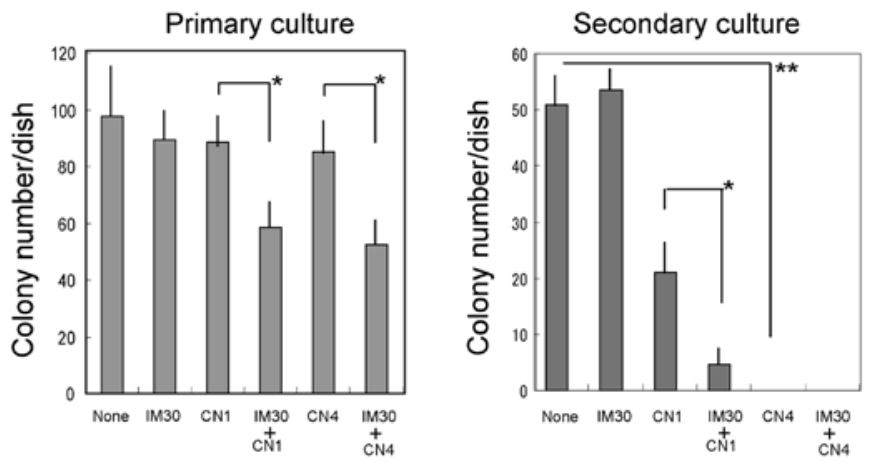

D
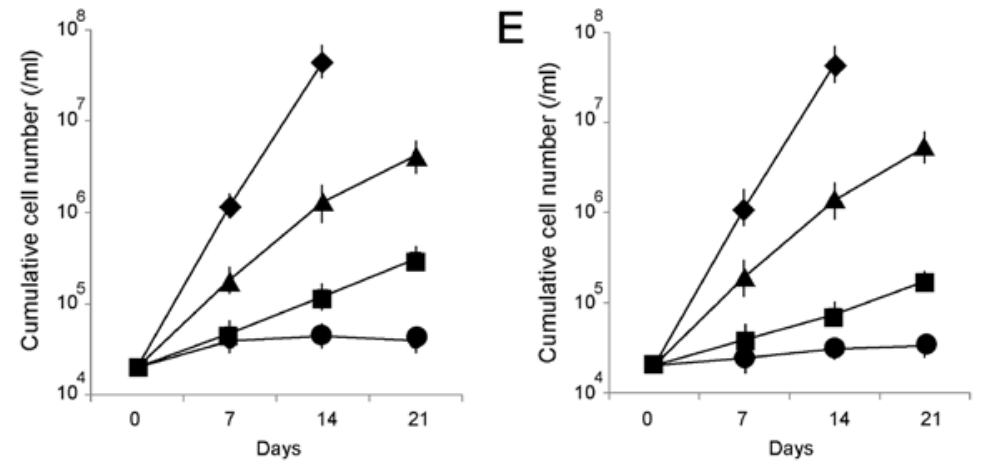

Figure 2. Combined effects of CN-A and IM on colony formation of primary CML cells. (A) Bone marrow mononuclear cells from a patient with CML (case 1) were plated in methylcellulose-containing medium and treated with $10 \mathrm{nM} \mathrm{IM}$ (IM10), $30 \mathrm{nM}$ IM (IM30), $1 \mu \mathrm{g} / \mathrm{ml} \mathrm{CN}-\mathrm{A}$ (CN1) or $4 \mu \mathrm{g} / \mathrm{ml} \mathrm{CN}-\mathrm{A}$ (CN4) for 7 days. The results are presented as the means \pm SD of 3 separate experiments. ${ }^{*} \mathrm{P}<0.05$. (B) Colony formation by primary CML (case 1 ) cells with $\mathrm{IM}$ and/or CN-A. Cells were cultured (a) without or with (b) $10 \mathrm{nM} \mathrm{IM}$, (c) $1 \mu \mathrm{g} / \mathrm{ml} \mathrm{CN-A}$, or (d) $10 \mathrm{nM}$ IM plus $1 \mu \mathrm{g} / \mathrm{ml} \mathrm{CN-A}$ for 7 days. (C) Combined treatment with CN-A and IM impaired serial colony formation by primary CML (case 2) cells. Cells were cultured without or with CN-A and/or IM for 7 days. The colony number was scored and cells were replated in secondary cultures with or without drugs for an additional 7 days. Results are presented as the means \pm SD of 3 separate experiments. ${ }^{*} \mathrm{P}<0.05,{ }^{* *} \mathrm{P}<0.01$. (D and E) Combined effects of CN-A and second-generation TKIs on the growth of KU812 cells

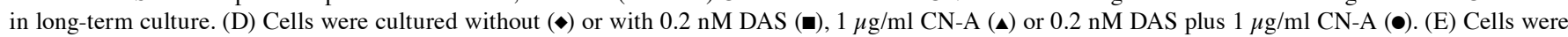
cultured without $(\bullet)$ or with $0.3 \mathrm{nM} \mathrm{NIL}(\bullet), 1 \mu \mathrm{g} / \mathrm{ml} \mathrm{CN-A} \mathrm{( \bullet )} \mathrm{or} 0.3 \mathrm{nM}$ NIL plus $1 \mu \mathrm{g} / \mathrm{ml} \mathrm{CN-A}(\bullet)$. Results are presented as the means \pm SD of $3 \mathrm{separate}$ experiments. IM, imatinib; CN-A, cotylenin A; CML, chronic myeloid leukemia.

cells. These same markers also apply to CML cells (19). Therefore, in this study, we examined the expression of CD38 in the $\mathrm{CN}$-A-treated cells. $\mathrm{CN}-\mathrm{A}$ at concentrations as low as $0.5 \mu \mathrm{g} / \mathrm{ml}$ efficiently converted the KU812 cells from CD38 to CD $38^{+}$(Fig. 3B), consistent with its role in promoting myeloid differentiation to an intermediate stage, but not to mature stages. IM did not affect CD38 expression even in the presence of CN-A.

Effect of CN-A on the expression of c-Myc and p21 in KU812 cells. A previous study indicated that the dual targeting of p53 and c-Myc selectively eliminated CML stem cells (4). Since p21 is a target gene of p53, we examined p21 expression as a marker of the p53 signal transduction pathway. CN-A effectively decreased the c-Myc protein level and increased the p21 protein level in the KU812 cells, while ATRA did not affect the c-Myc protein level and decreased the p21 protein level (Fig. 4A). IM did not affect the protein levels of p21 or c-Myc in the KU812 cells, even in the presence of CN-A (Fig. 4B). We then examined the effect of CN-A on c-Myc mRNA expression in the KU812 cells. The downregulation of c-Myc mRNA by CN-A was observed within $6 \mathrm{~h}$ (Fig. 4C), suggesting that it is an early event in the action of CN-A. Neither IM nor ATRA affected mRNA expression (Fig. 4D).

\section{Discussion}

In the present study, the combination of TKIs and CN-A was found to be more effective than either drug used alone at reducing the CML cell bulk, and TKIs did not interfere 
A
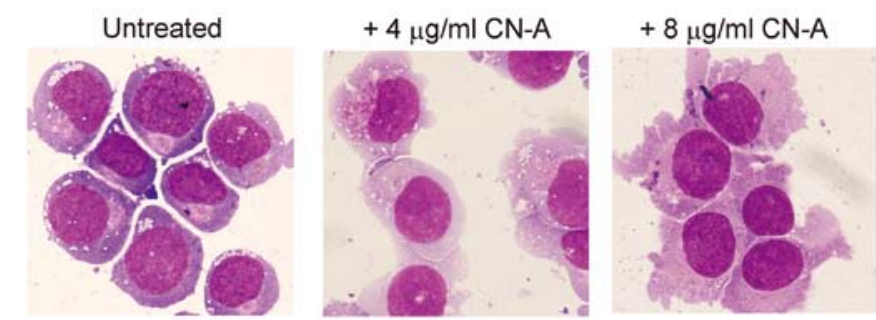

$+50 \mathrm{nM} \mathrm{IM}$

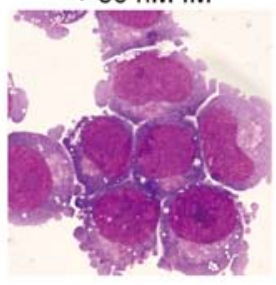

+300 nM ATRA

$+1.25 \mathrm{nM}$ AraC
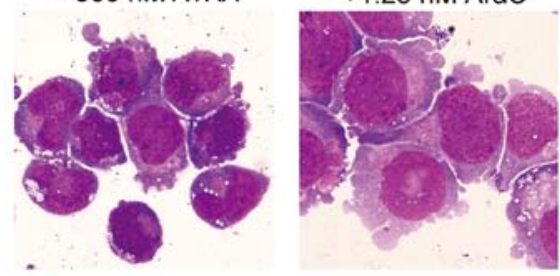

B
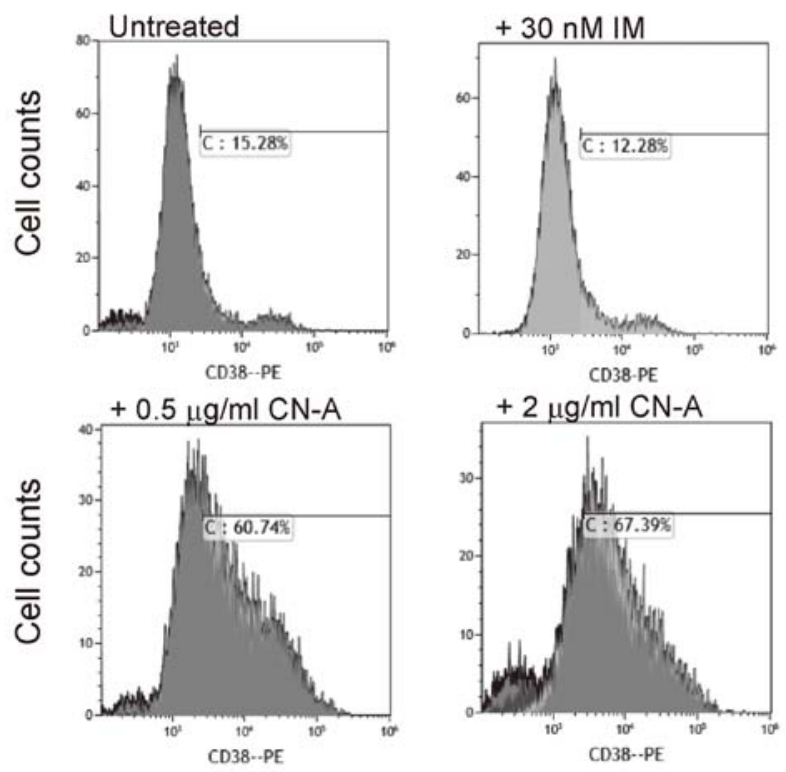

Figure 3. (A) Morphological changes in KU812 cells treated with CN-A. Cells were treated as indicated. After 5 days, the cells were stained with May-Grünwald-Giemsa solution. (B) Induction of CD38 expression on KU812 cells by CN-A. Cells were treated as indicated for 4 days.

with the detrimental effect of $\mathrm{CN}-\mathrm{A}$ on stem cell potential or clonogenic activity.

Differentiation-inducing agents can alter the phenotype of cancer cells. A previous study indicated that ATRA converted KCL-22 CML cells from CD38- to CD38+ cells (20), and the results of the present study demonstrated that ATRA effectively inhibited the growth of KU812 cells (Table I). However, ATRA did not affect the growth of the K562 cells and did not effectively convert the KU812 cells from CD38 to $\mathrm{CD} 38^{+}$cells. $\mathrm{CN}-\mathrm{A}$ altered the phenotype of CML cells more effectively than ATRA. In a previous study, CN-A affected the differentiation of leukemic cells that had been freshly isolated from patients with AML in primary culture. It significantly stimulated both the functional and morphological differentiation of leukemia cells in 9 of 12 cases. Its differentiation-inducing activity was shown to be more potent than those of ATRA and VD3 (13). However, CN-A did not induce CD11b or NBT reduction in CML cells, although it induced CD38 expression. These results indicated that $\mathrm{CN}-\mathrm{A}$ induces the differentiation of CML cells to an intermediate stage. Previous studies have indicated that $\mathrm{CN}-\mathrm{A}$ and related compounds inhibit clonogenic activity, cell-surface expression of cancer stem cell markers and stemness-associated gene expression in some malignant cells (21-23). CN-A and related compounds have been shown to significantly inhibit the growth of malignant cells as xenografts without apparent adverse effects $(22,24)$. Combined treatment with $\mathrm{CN}-\mathrm{A}$ and TKIs had a selective cytotoxic effect on more primitive LSCs at clinically tolerable doses.

A receptor of fusicoccin, which is closely related to CN-A, has been reported to be a member of a family of 14-3-3 proteins that are commonly found in a wide variety of signaling and regulatory pathways (25). The 14-3-3 proteins bind to discrete phosphoserine-containing motifs present in many signaling molecules. The 14-3-3 proteins are associated with dynamic nucleo-cytoplasmic shuttling. A number of nuclear proteins can become phosphorylated, bind to 14-3-3 proteins and accumulate in the cytoplasm. The 14-3-3 proteins negatively regulate histone deacetylase 4 (26) and cyclindependent kinase inhibitor p27 (27) by preventing their 
A

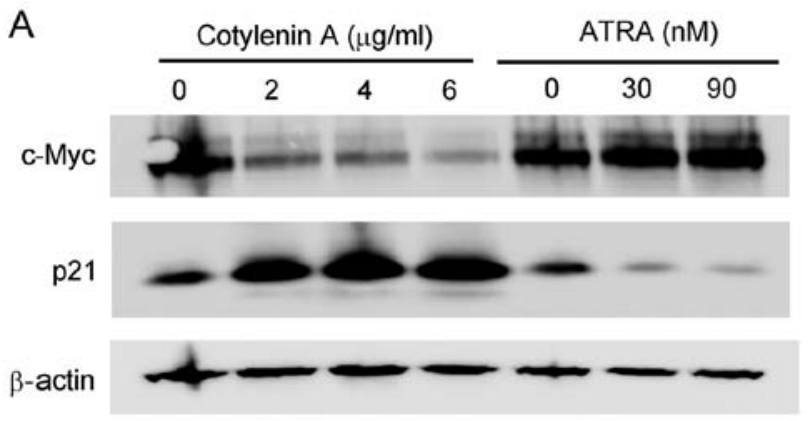

B
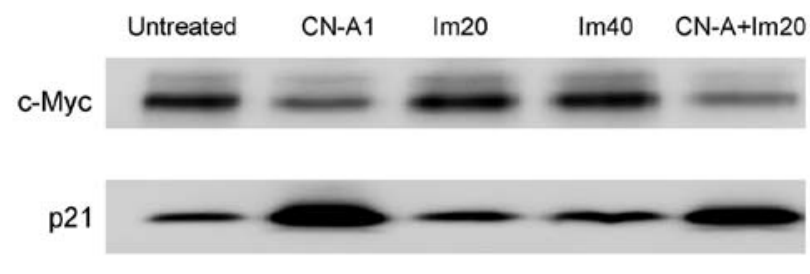

$\beta$-actin

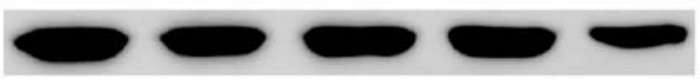

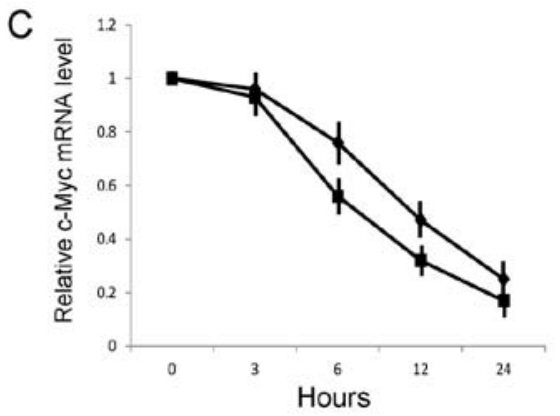

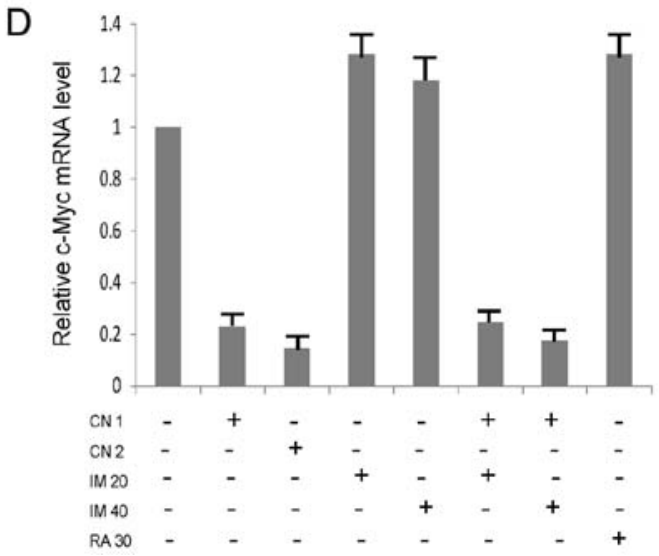

Figure 4. (A and B) Western blot analyses for c-Myc and p21 proteins. KU812 cells were treated with (A) CN-A or ATRA for 4 days. (B) Cells were treated with $1 \mu \mathrm{g} / \mathrm{ml} \mathrm{CN}-\mathrm{A}$ (CN-A1), $20 \mathrm{nM}$ IM (IM20), $40 \mathrm{nM}$ IM (IM40) or $1 \mu \mathrm{g} / \mathrm{ml} \mathrm{CN-A}$ plus $20 \mathrm{nM}$ IM (CN-A + IM20) for 4 days. Similar results were obtained in two additional experiments. (C) Downregulation of the c-Myc mRNA level in KU812 cells by CN-A. Cells were cultured with $1(\bullet)$ or $2(\mathbf{\bullet}) \mu \mathrm{g} / \mathrm{ml} \mathrm{CN}-\mathrm{A}$ for the indicated periods of time. Results are presented as the means \pm SD of 3 separate experiments. (D) Combined effects of IM and CN-A or ATRA on the c-Myc RNA level in KU812 cells. Cells were treated with IM and/or CN-A (CN) or ATRA (RA) for $24 \mathrm{~h}$. Results are presented as the means \pm SD of 3 separate experiments.

nuclear localization. A special subfamily of 14-3-3 proteins may bind $\mathrm{CN}-\mathrm{A}$ and affect its interaction with some signaling molecules. This modification may lead to downregulation of the c-Myc gene (Fig. 4), which is an early gene that is suppressed by $\mathrm{CN}-\mathrm{A}$ in $\mathrm{CML}$ cells. c-Myc upregulates $\mathrm{BCR} / \mathrm{ABL}$ expression and is necessary for BCR/ABL-induced transformation and LSC maintenance (28). However, further studies are warranted in order to elucidate the mechanism through which the downregulation of c-Myc is related to the effects of $\mathrm{CN}-\mathrm{A}$ on the 14-3-3 signaling pathway.

Discontinuation trials with second generation TKIs have shown that $40-50 \%$ of patients with CML maintain the treatment response without continued therapy. However, cardiopulmonary adverse effects are now impacting treatment choice $(29,30)$. Therefore, more effective TKI therapy combined with targeted therapy against pathways involved in CML-LSC survival should be explored. CML-LSCs have been extensively characterized, with the aim of developing novel curative approaches based on the eradication of LSCs. A number of potential molecular targets have been identified to eradicate LSCs in CML. Several studies have presented other possible targets to eliminate LSCs in CML therapy in combination with TKIs. These include interleukin-1 signaling, hypoxia-inducible factor and mitochondrial oxidative phosphorylation (31-34). At present, however, no drug is available for clinical use against these targets. A number of pathways and mechanisms may promote the survival of LSCs in CML. Therefore, the dual or triple inhibition of these targets may be more effective in the treatment of CML with TKIs.

\section{Acknowledgements}

Not applicable.

\section{Funding}

The present study was supported in part by the SUIGAN Project, Shimane University, Japan.

\section{Availability of data and materials}

The analyzed datasets generated during the study are available from the corresponding author on reasonable request.

\section{Authors' contributions}

YH, TO and JS designed the study. FI and YH performed the experiments. YH, TU and JS wrote, edited and revised the manuscript critically for important intellectual content. FI and YH analyzed the results. All authors have read and approved the final manuscript.

\section{Ethics approval and consent to participate}

Leukemic bone marrow specimens were collected at diagnosis, after the patients provided written informed consent for sample collection in accordance with institutional policy. The Shimane University Institutional Committee on Ethics (Shimane, Japan) approved the present study. 


\section{Consent for publication}

Not applicable.

\section{Competing interests}

The authors declare that they have no competing interests.

\section{References}

1. Graham SM, Jørgensen HG, Allan E, Pearson C, Alcorn MJ, Richmond L and Holyoake TL: Primitive, quiescent, Philadelphiapositive stem cells from patients with chronic myeloid leukemia are insensitive to STI571 in vitro. Blood 99: 319-325, 2002.

2. Mahon FX, Réa D, Guilhot J, Guilhot F, Huguet F, Nicolini F, Legros L, Charbonnier A, Guerci A, Varet B, et al; Intergroupe Français des Leucémies Myéloïdes Chroniques: Discontinuation of imatinib in patients with chronic myeloid leukaemia who have maintained complete molecular remission for at least 2 years: The prospective, multicentre Stop Imatinib (STIM) trial. Lancet Oncol 11: 1029-1035, 2010.

3. Corbin AS, Agarwal A, Loriaux M, Cortes J, Deininger MW and Druker BJ: Human chronic myeloid leukemia stem cells are insensitive to imatinib despite inhibition of BCR-ABL activity. J Clin Invest 121: 396-409, 2011.

4. Abraham SA, Hopcroft LE, Carrick E, Drotar ME, Dunn K, Williamson AJ, Korfi K, Baquero P, Park LE, Scott MT, et al: Dual targeting of p53 and c-MYC selectively eliminates leukaemic stem cells. Nature 534: 341-346, 2016.

5. Collins SJ, Bodner A, Ting R and Gallo RC: Induction of morphological and functional differentiation of human promyelocytic leukemia cells (HL-60) by componuds which induce differentiation of murine leukemia cells. Int J Cancer 25: 213-218, 1980.

6. Honma Y: Cotylenin A - a plant growth regulator as a differentiationinducing agent against myeloid leukemia. Leuk Lymphoma 43: 1169-1178, 2002.

7. Ishii $\mathrm{Y}$, Kasukabe $\mathrm{T}$ and Honma $\mathrm{Y}$ : Immediate up-regulation of the calcium-binding protein S100P and its involvement in the cytokinin-induced differentiation of human myeloid leukemia cells. Biochim Biophys Acta 1745: 156-165, 2005.

8. Ishii Y, Kasukabe T and Honma Y: Induction of CCAAT/enhancer binding protein-delta by cytokinins, but not by retinoic acid, during granulocytic differentiation of human myeloid leukaemia cells. Br J Haematol 128: 540-547, 2005.

9. Tsumura $\mathrm{H}$, Akimoto $\mathrm{M}$, Kiyota $\mathrm{H}$, Ishii $\mathrm{Y}$, Ishikura $\mathrm{H}$ and Honma Y: Gene expression profiles in differentiating leukemia cells induced by methyl jasmonate are similar to those of cytokinins and methyl jasmonate analogs induce the differentiation of human leukemia cells in primary culture. Leukemia 23: 753-760, 2009.

10. Liebermann DA and Hoffman B: Differentiation primary response genes and proto-oncogenes as positive and negative regulators of terminal hematopoietic cell differentiation. Stem Cells 12: 352-369, 1994.

11. Dimberg A, Bahram F, Karlberg I, Larsson LG, Nilsson K and Oberg F: Retinoic acid-induced cell cycle arrest of human myeloid cell lines is associated with sequential down-regulation of c-Myc and cyclin E and post-transcriptional up-regulation of p27(Kip1). Blood 99: 2199-2206, 2002.

12. Hu XT and Zuckerman KS: Role of cell cycle regulatory molecules in retinoic acid- and vitamin D3-induced differentiation of acute myeloid leukaemia cells. Cell Prolif 47: 200-210, 2014.

13. Yamada K, Honma Y, Asahi KI, Sassa T, Hino KI and Tomoyasu S: Differentiation of human acute myeloid leukaemia cells in primary culture in response to cotylenin A, a plant growth regulator. $\mathrm{Br} \mathrm{J}$ Haematol 114: 814-821, 2001.

14. Honma Y, Ishii Y, Sassa T and Asahi K: Treatment of human promyelocytic leukemia in the SCID mouse model with cotylenin A, an inducer of myelomonocytic differentiation of leukemia cells. Leuk Res 27: 1019-1025, 2003.

15. Lozzio BB and Lozzio CB: Properties of the K562 cell line derived from a patient with chronic myeloid leukemia. Int $\mathrm{J}$ Cancer 19: 136, 1977.
16. Kishi K: A new leukemia cell line with Philadelphia chromosome characterized as basophil precursors. Leuk Res 9: 381-390, 1985.

17. Maniwa Y, Kasukabe T and Kumakura S: Vitamin K2 and cotylenin A synergistically induce monocytic differentiation and growth arrest along with the suppression of c-MYC expression and induction of cyclin G2 expression in human leukemia HL-60 cells. Int J Oncol 47: 473-480, 2015.

18. Livak KJ and Schmittgen TD: Analysis of relative gene expression data using real-time quantitative PCR and the $2(-\Delta \Delta \mathrm{C}(\mathrm{T}))$ method. Methods 25: 402-408, 2001.

19. Terstappen LW, Huang S, Safford M, Lansdorp PM and Loken MR: Sequential generations of hematopoietic colonies derived from single nonlineage-committed CD34 ${ }^{+} \mathrm{CD} 38$ progenitor cells. Blood 77: 1218-1227, 1991.

20. Wang Z, Liu Z, Wu X, Chu S, Wang J, Yuan H, Roth M, Yuan YC, Bhatia R and Chen W: ATRA-induced cellular differentiation and CD38 expression inhibits acquisition of BCR-ABL mutations for CML acquired resistance. PLoS Genet 10: e1004414, 2014.

21. Takahashi T,Honma Y, Miyake T, Adachi K, Takami S, Okada M, Kumanomidou S, Ikejiri F, Jo Y, Onishi C, et al: Synergistic combination therapy with cotylenin A and vincristine in multiple myeloma models. Int J Oncol 46: 1801-1809, 2015.

22. Kawakami K, Hattori M, Inoue T, Maruyama Y, Ohkanda J, Kato N, Tongu M, Yamada T, Akimoto M, Takenaga K, et al: A novel fusicoccin derivative preferentially targets hypoxic tumor cells and inhibits tumor growth in xenografts. Anticancer Agents Med Chem 12: 791-800, 2012.

23. Miyake T, Honma Y, Urano T, Kato N and Suzumiya J: Combined treatment with tamoxifen and a fusicoccin derivative (ISIR-042) to overcome resistance to therapy and to enhance the antitumor activity of 5-fluorouracil and gemcitabine in pancreatic cancer cells. Int J Oncol 47: 315-324, 2015.

24. Honma Y, Ishii Y, Yamamoto-Yamaguchi Y, Sassa T and Asahi K: Cotylenin A, a differentiation-inducing agent, and IFN-alpha cooperatively induce apoptosis and have an antitumor effect on human non-small cell lung carcinoma cells in nude mice. Cancer Res 63: 3659-3666, 2003.

25. Oecking C, Eckerskorn $\mathrm{C}$ and Weiler EW: The fusicoccin receptor of plants is a member of the 14-3-3 superfamily of eukaryotic regulatory proteins. FEBS Lett 352: 163-166, 1994.

26. Rittinger K, Budman J, Xu J, Volinia S, Cantley LC, Smerdon SJ, Gamblin SJ and Yaffe MB: Structural analysis of 14-3-3 phosphopeptide complexes identifies a dual role for the nuclear export signal of 14-3-3 in ligand binding. Mol Cell 4: 153-166, 1999.

27. Fujita N, Sato S and Tsuruo T: Phosphorylation of p27Kip1 at threonine 198 by p90 ribosomal protein S6 kinases promotes its binding to 14-3-3 and cytoplasmic localization. J Biol Chem 278: 49254-49260, 2003.

28. el-Deiry WS, Tokino T, Velculescu VE, Levy DB, Parsons R, Trent JM, Lin D, Mercer WE, Kinzler KW and Vogelstein B: WAF1, a potential mediator of p53 tumor suppression. Cell 75: 817-825, 1993.

29. Moslehi JJ and Deininger M: Tyrosine kinase inhibitorassociated cardiovascular toxicity in chronic myeloid leukemia. J Clin Oncol 33: 4210-4218, 2015.

30. Caldemeyer L, Dugan M, Edwards J and Akard L: Long-term side effects of tyrosine kinase inhibitors in chronic myeloid leukemia. Curr Hematol Malig Rep 11: 71-79, 2016.

31. Ågerstam H, Hansen N, von Palffy S, Sandén C, Reckzeh K, Karlsson C, Lilljebjörn H, Landberg N, Askmyr M, Högberg C, et al: IL1RAP antibodies block IL-1-induced expansion of candidate CML stem cells and mediate cell killing in xenograft models. Blood 128: 2683-2693, 2016.

32. Zhang B, Chu S, Agarwal P, Campbell VL, Hopcroft L, Jørgensen HG, Lin A, Gaal K, Holyoake TL and Bhatia R: Inhibition of interleukin-1 signaling enhances elimination of tyrosine kinase inhibitor-treated CML stem cells. Blood 128: 2671-2682, 2016.

33. Cheloni G, Tanturli M, Tusa I, Ho DeSouza N, Shan Y, Gozzini A, Mazurier F, Rovida E, Li S and Dello Sbarba P: Targeting chronic myeloid leukemia stem cells with the hypoxia-inducible factor inhibitor acriflavine. Blood 130: 655-665, 2017.

34. KuntzEM,Baquero P,Michie AM,Dunn K, Tardito S, Holyoake TL, Helgason GV and Gottlieb E: Targeting mitochondrial oxidative phosphorylation eradicates therapy-resistant chronic myeloid leukemia stem cells. Nat Med 23: 1234-1240, 2017. 